Article

\title{
The Combination of Wildfire and Changing Climate Triggers Permafrost Degradation in the Khentii Mountains, Northern Mongolia
}

\author{
Munkhdavaa Munkhjargal ${ }^{1, *(\mathbb{D})}$, Gansukh Yadamsuren ${ }^{2}$, Jambaljav Yamkhin ${ }^{2}$ and \\ Lucas Menzel ${ }^{1}$ \\ 1 Professorship in Hydrology and Climatology, Institute of Geography, Heidelberg University, Im \\ Neuenheimer Feld 348, 69120 Heidelberg, Germany; lucas.menzel@uni-heidelberg.de \\ 2 Permafrost Division, Institute of Geography and Geoecology, Mongolian Academy of Science, Erkhuu Street, \\ Sukhbaatar District, UB-14192 Ulaanbaatar, Mongolia; gansukh.khatan@gmail.com (G.Y.); \\ jambaljav@gmail.com (J.Y.) \\ * Correspondence: munkhjargal@uni-heidelberg.de; Tel.: +49-6221-54-5571
}

Received: 3 December 2019; Accepted: 30 January 2020; Published: 31 January 2020

check for updates

\begin{abstract}
High topographic heterogeneity and complex mechanisms between the atmosphere and the ground create unique hydro-climatic processes over mountainous regions. Based on in situ observations, we present the spatial variability of ground surface temperature (GST) in the Khentii Mountains of northern Mongolia, which is situated at the southern fringe of the Eurasian permafrost zone. Changes in the hydrothermal regime of the active layer were investigated in association with changing climate and wildfire effects. The results reveal that the GST tends to increase continuously since 2011 in both thawing and freezing seasons, and varies significantly within a short horizontal distance, particularly during the thawing season. Extreme weather events, such as drought and heavy snowfall, amplify the increase in the ground temperature and deepen the seasonal thawing depth. The fire-induced loss in organic layer resulted in a greater heat penetration deeper into the ground and unbalanced the moisture distribution. Overall, the thawing depth is greater by $>1.7 \mathrm{~m}$ under severely burned forest, compared to unburned forest. Given that about $30 \%$ of the boreal forest was affected by wildfire in the study area, the ground thermal regime changed considerably. The findings suggest that the combination of regional temperature rise and more frequent extreme weather and wildfire events in the region triggers permafrost degradation and alters the hydrothermal regime in the future.
\end{abstract}

Keywords: wildfire; active layer; permafrost degradation; hydrothermal regime; mountain region

\section{Introduction}

The boreal forest biome in Siberia largely overlaps with the Eurasian discontinuous permafrost zone. The permafrost (perennially frozen ground for at least two consecutive years) temperature is typically very close to thawing in the southern fringe of this widespread permafrost region and is potentially vulnerable to changes in climate and surface cover disturbances [1,2]. Degrading permafrost due to rising air temperature is already evident in the southern boundary of Siberia (northern Mongolia), as well as on a global scale [3-5]. For instance, air temperature increased by $2{ }^{\circ} \mathrm{C}$ in Mongolia since $1940[6,7]$. Despite the warming climate, the moss layer underneath boreal forest plays a significant role in creating cold subsurface conditions during the thawing season, when air temperature is above $0{ }^{\circ} \mathrm{C}$. This heat insulation effect of the organic materials between the atmosphere and the ground surface is due to its low thermal conductivity $(K)$, thus favoring permafrost presence. During the freezing season when air temperature remains below $0{ }^{\circ} \mathrm{C}$, the seasonal snow cover has the reverse insulating 
effect, keeping the ground warmer than the ambient air. Therefore, the energy balance on the ground surface is a result of multiple factors, including microclimate, air temperature, organic layer, snow accumulation, soil moisture, and topography [8].

An active layer that freezes and thaws seasonally develops above the permafrost, in which most hydrological processes occur. However, the link between hydrological processes and permafrost thaw remains elusive [9]. In addition to globally rising temperature, the increased frequency of wildfires is a major problem across the Siberian boreal forest area [10]. The effect of wildfire includes thickening of the active layer, talik development (a year-round unfrozen layer between the active layer and permafrost table), and permafrost degradation, which subsequently changes the hydrological regime [11,12]. In discontinuous or sporadic permafrost regions, taliks can develop both vertically and laterally, thus limiting the volume of perennially frozen ground [13]. Therefore, forest fire coupled with increasing air temperature can seriously affect both the extent and the thickness of permafrost. However, the rate of permafrost thaw differs especially across the discontinuous permafrost zone depending on site-specific factors, such as fire severity, soil thermal conductivity, and the characteristics of water movement within the active layer [14-16].

The heat transfer from ground surface to permafrost table is driven primarily by the process of heat conduction [17], which is modulated by the available soil water content (SWC) due to the partitioning of the latent heat energy. Based on field observations, several studies reported increased SWC in the upper horizon of the soil column after fire in Siberian continuous and discontinuous permafrost areas $[18,19]$, while others saw decreases or no change after a fire but increased water storage in the thawed soil above the permafrost table [20,21]. In mid- and small-scale watersheds affected by wildfire, Semenova et al. (2015) found both increasing and unchanged river discharge in the continuous permafrost region of Siberia [22]. However, the exact effect of wildfire on the soil hydraulic properties and hydrological regime is not well understood and differs depending on location. Some research suggests that water infiltration decreases after fire due to the development of a soil hydrophobic layer (a thin soil layer in which pores are filled by ashes and organic material), drainage increases, and the combusted organic layer absorbs less rainfall and snowmelt water [23-25].

Although the hydrothermal dynamics of active layers is relatively well documented in northern Mongolia [26,27], the influences of snow and vegetation cover, as well as wildfire, on ground surface temperature (GST) are not yet documented due to data scarcity and logistic inaccessibility. Here, we present data from field investigations conducted in Sugnugur Valley, Khentii Mountains in northern Mongolia (Figure 1). The objective of this study was to (i) identify the spatial variability of GST, (ii) understand the response of the ground hydrothermal regime to changes in extreme weather variability such as thick snow cover and drought, and (iii) assess the effect of wildfire on active layer dynamics and permafrost stability.

The study area is characterized as a semi-arid environment with extreme continental climate, high variability in seasonal temperature, and low precipitation. Mean annual air temperature (MAAT) is $-1.07^{\circ} \mathrm{C}$ at $1193 \mathrm{~m}$ above sea level (a.s.l.). The annual precipitation is $350 \mathrm{~mm}$, about $70 \%$ of which is received during summer (June, July, and August). The elevation ranges from 960 to $2800 \mathrm{~m}$ a.s.l in the Sugnugur catchment. Seasonal snow cover with a mean depth of 18-20 cm lasts for 124-226 days with an elevational gradient of +6 days/100 $\mathrm{m}$ [28]. The Sugnugur Valley trends east to west, resulting in north- and south-facing slopes with distinct vegetation covers [29]. A dry steppe on silty soil dominates the south-facing slope. On the northerly exposed slopes, a 15-20-cm-thick moss layer, which is covered by boreal forest and underlain by a silty clay soil, is present [30]. In the valley bottom, shrubs are scattered with short grass underneath. The Sugnugur catchment is the headwater stream area of Kharaa River, which eventually drains to Lake Baikal via Selenga River [31].

The study area is in the discontinuous permafrost region or southern fringe of Eurasian widespread permafrost. In such a region, permafrost presence is a result of a complex interaction between climatic and biophysical factors that are highly variable in space and time, and it is protected by the thick organic layer under forest canopy [32]. About $30 \%$ of the forest in the valley was affected by wildfire [18]. 
The forest on the north-facing slope where we conducted the study was partially burned in 2009 [33], and there is barely any sign of recovery visible after a decade. Overland flow on the south-facing slope and lateral subsurface flow on the north-facing slope are predominant [30]. The abbreviations used in the study are described in Table 1.

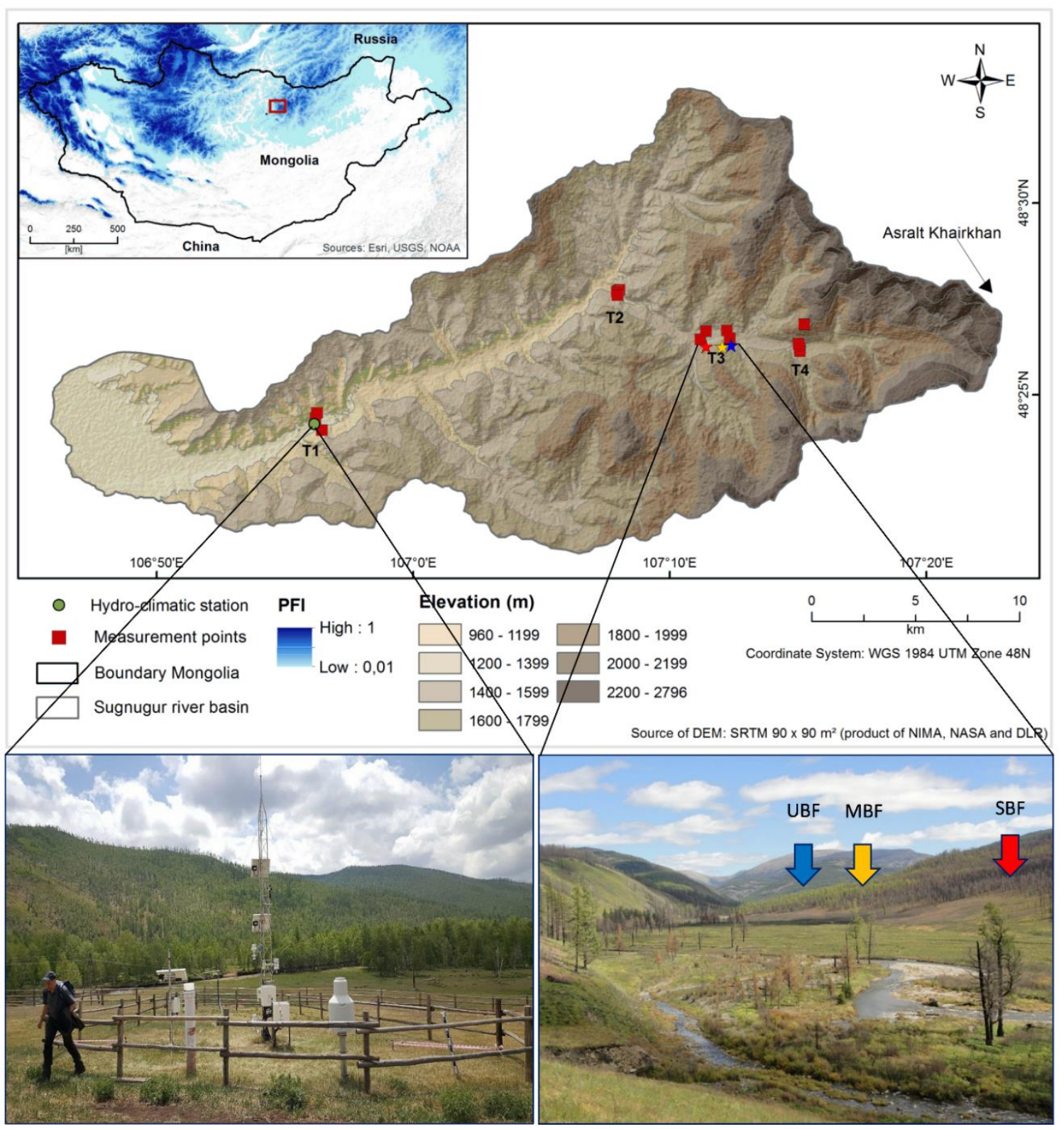

Figure 1. The locations of study area and in situ measurements. Photographs show the hydro-climatic station near the valley entry and unburned (UBF), moderate burned (MBF), and severely burned (SBF) forests on the same north-facing slope in the upper valley. The inset image illustrates the permafrost favorability index (PFI) on a global scale [34]. Measurement points indicate the locations of biomass, accumulated snow depth, thermal conductivity, and ground surface temperature (GST) measurements as cross-valley transects (on south- and north-facing slopes and in valley bottom) (T1-T4). 
Table 1. List of abbreviations used in the study.

\begin{tabular}{cccc}
\hline Abbreviation & Explanation & Abbreviation & Explanation \\
\hline MAAT & Mean annual air temperature & MBF & Moderate burned forest \\
\hline GST & Ground surface temperature & TDDs & Surface thawing degree-days \\
\hline ASD & Accumulated snow depth & FDDs & Surface freezing degree-days \\
\hline K & Soil thermal conductivity & SWC & Soil water content \\
\hline SBF & Severely burned forest & MAGT & Mean annual ground temperature \\
\hline UBF & Unburned forest & SCD & Snow cover duration \\
\hline
\end{tabular}

\section{Materials and Methods}

We recorded over 40 hydro-meteorological variables at high temporal resolution at a non-permafrost site near the entry of Sugnugur Valley since 2011 (hereafter called the hydro-climatic station) (Figure 1). These variables include the standard climatic parameters, soil temperature, and soil moisture at various depths, all radiation components, and snow depth, among others [35]. The GST regime was analyzed during the observation period by determining the surface freezing $\left(\mathrm{FDD}_{\mathrm{s}}\right)$ and thawing $\left(\mathrm{TDD}_{\mathrm{s}}\right)$ total degree-days. The insulating effect of seasonal snow cover on GST was analyzed using the freezing $n$-factor $\left(n_{f}\right)$, which is the ratio between $\mathrm{FDD}_{\mathrm{s}}$ and $\mathrm{FDD}_{\mathrm{a}}$ (air) temperatures during freezing season [8].

$$
n f=\frac{F D D s}{\text { FDDa }}
$$

We calculated the thawing depth in a severely burned forest (SBF) and unburned forest (UBF) using the Stefan's model (Equation (2)), which is a simple but well-known heat transfer approach [36]. This approach invokes many assumptions, including no horizontal heat transfer, constant moisture content with depth, uniform thermal conductivity, negligible soil heat capacity, and no heat advection [9].

$$
Z(m)=\sqrt{\frac{2 K I(t)}{L \theta \rho}},
$$

where $Z$ is the thawing depth (active layer thickness), $K$ is the thermal conductivity of thawed soil, $I(t)$ is the total thawing degree days at surface, $L$ is the latent heat of fusion required for phase change, $\theta$ is the soil volumetric water content, and $\rho$ is the water density.

The spatial variability of accumulated snow depth (ASD) was studied at different elevations, topographic settings, and land covers including the burned and unburned forests in late winters between 2016-2017 and 2018-2019. The effect of vegetation cover (sampled as net biomass with $50 \times 50 \mathrm{~cm}$ plots) on GST during the thawing season 2017 was analyzed using temperature iButton measurements (placed at $\sim 5$-cm depth, accuracy of $\pm 0.25{ }^{\circ} \mathrm{C}$, maxim integrated) at all snow measurement sites. Moreover, we also measured the thawed soil thermal conductivities at 10-, 20-, and 40-cm depths using a Decagon KD2 Pro thermal conductivity meter to observe the variability of heat flow to deeper ground in different topography and ecosystems during thawing season 2017 (Table 2).

Lastly, three soil pits were excavated up to the frost table under SBF (at 0-290 cm, from December 2015 to September 2018), moderate burned forest (MBF) (at 0-230 cm, from December 2015 to September 2016) and UBF (at 0-120 cm, from September 2016 to September 2018) to observe changes in soil temperature and moisture (Figure 2). In total, seven moisture sensors (Decagon probe 10HS, accuracy $0.033 \mathrm{~m}^{3} / \mathrm{m}^{3}$ ) and eight temperature sensors (TMC20-HD probe, accuracy $\pm 0.25^{\circ} \mathrm{C}$ ) were installed at each pit. The categorization of fire severity was determined visually based on the affected number of trees. Following the installation of sensors, the pits were backfilled with the excavated material, preserving the original layering and ground cover as much as possible. 

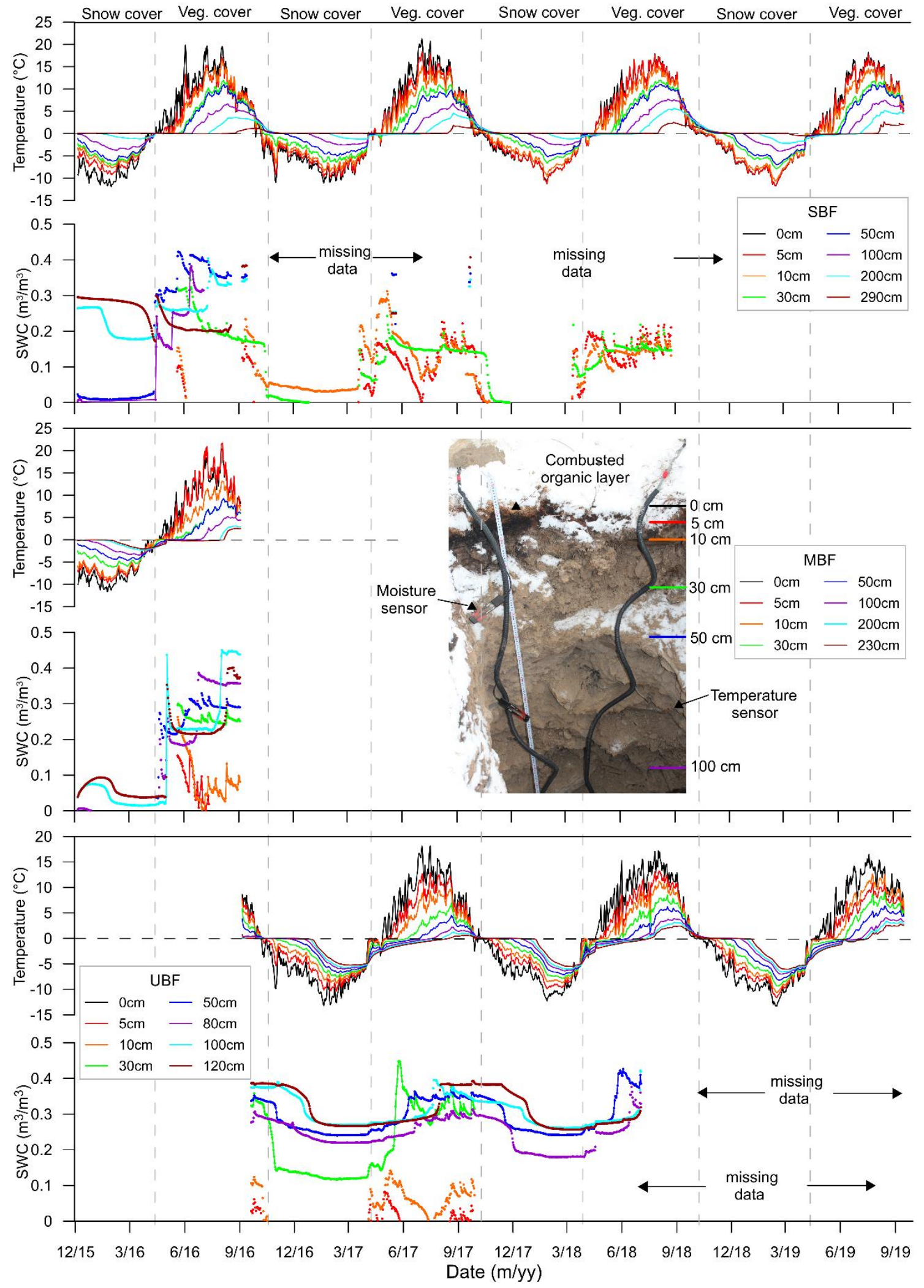

Figure 2. Observed soil temperature and water content (SWC) in the pits at severely burned (SBF), moderate burned (MBF), and unburned (UBF) forest sites. Moisture and temperature sensors were shifted from MBF to UBF in September 2016. The inset photograph from the MBF site illustrates the general positioning of the sensors and soil profile. 
Table 2. Summary of the observed ground surface temperature from iButton and field measurements in Sugnugur catchment for the year 2016-2017. TDD ${ }_{\mathrm{S}}$ and $\mathrm{FDD}_{\mathrm{S}}$ stand for surface thawing degree-days and surface freezing degree-days, respectively. $K$ and ASD represent soil thermal conductivity at $20 \mathrm{~cm}$ and accumulated snow depth. T denotes the transect number, while PSR stands for daily potential solar radiation.

\begin{tabular}{|c|c|c|c|c|c|c|c|c|c|c|}
\hline & \multirow{2}{*}{$\mathbf{T}$} & \multirow{2}{*}{ Altitude (m) } & \multirow{2}{*}{ Aspect } & \multirow{2}{*}{ Vegetation Type } & \multicolumn{5}{|c|}{ Field Measurements } & \multirow{2}{*}{$\begin{array}{c}\text { PSR } \\
\mathbf{W} \cdot \mathbf{m}^{-2}\end{array}$} \\
\hline & & & & & TDDs $\left({ }^{\circ} \mathrm{C}\right)$ & FDDs $\left({ }^{\circ} \mathrm{C}\right)$ & $K\left(\mathrm{Wm}^{-1} \cdot \mathrm{K}^{-1}\right)$ & Biomass $\left(\mathrm{kg} / \mathrm{m}^{2}\right)$ & $A S D(\mathrm{~cm})$ & \\
\hline 1 & \multirow[b]{2}{*}{1} & 1281 & South & Sparse vegetation & 3391 & -1000 & 0.56 & 0.035 & - & 182 \\
\hline 2 & & 1193 & Valley & Short grass & 2770 & -948 & 0.7 & 0.06 & 23 & 175 \\
\hline 4 & \multirow{3}{*}{2} & 1393 & South & Sparse vegetation & 2905 & -1548 & 0.58 & 0.24 & 0 & 172 \\
\hline 5 & & 1356 & Valley & Shrub & 2141 & -1597 & 0.78 & 0.875 & 20 & 145 \\
\hline 6 & & 1393 & North & Dense forest & 1498 & -1356 & 0.72 & 3.975 & 22 & 111 \\
\hline 9 & \multirow[t]{2}{*}{3} & 1558 & North & $\mathrm{UBF}$ & 1647 & -1282 & 0.73 & 4.95 & 21 & 149 \\
\hline 10 & & 1530 & North & SBF & - & - & 1.15 & 2.46 & 27 & 158 \\
\hline 11 & \multirow{3}{*}{4} & 1583 & Valley & Shrub & 1482 & -1855 & 0.69 & 1.67 & 12 & 148 \\
\hline 12 & & 1612 & North & Sparse forest & 2050 & -1322 & 0.5 & 2.43 & 25 & 140 \\
\hline 13 & & 2020 & Mnt. & Rock & 1705 & -956 & - & - & - & 196 \\
\hline
\end{tabular}

Due to malfunctioning sensors and external damage, there were some gaps mostly in soil moisture data. As the pits were located close to each other on the same north-facing slope ( 100 $\mathrm{m}$ to MBF and $\sim 600 \mathrm{~m}$ to SBF sites, respectively, from the UBF site), we assumed that the pre-fire organic layer condition was similar for all three sites. During the pit excavation work in December 2015, the soil textures and water contents were determined at the SBF and MBF sites (Supplementary Materials, Table S1).

\section{Results and Discussion}

Permafrost in the southern fringe of Eurasian permafrost is warm, protected by boreal forest, and highly sensitive to climate change and environmental disturbances, such as wildfire. In this region, the projections of future climate indicate further temperature increases with more frequent extreme weather events, including heavy snowfall and droughts. Permafrost vulnerability to climate change may be underestimated unless effects of wildfire are considered [12]. Although wildfire in boreal forests is a natural phenomenon, its frequency increased significantly $[37,38]$. Mean fire return in Siberia ranges from 20 to 350 years, with a drastic increase in the southern part due to frequent dry seasons and changes in human behavior [39,40]. The impact of wildfire on permafrost stability is not well documented due to data scarcity and logistic inaccessibility. Based on ground observations, we present our preliminary results on the response of ground hydrothermal regime and permafrost stability to a combination of wildfire and extreme climatic events in the Khentii Mountains, northern Mongolia.

\subsection{Temperature Variability}

The observed MAAT and ASD showed high variabilities at the hydro-climatic station site ranging from -2.49 to $-0.27^{\circ} \mathrm{C}$ for $2011-2018$ and 5 to $31 \mathrm{~cm}$ for winters 2011-2012 to 2018-2019, respectively (Figure S1, Supplementary Materials). The ground thermal regime and permafrost presence are not only driven by air temperature, but also by the insulating effects of seasonal snow and overlaying vegetation cover. Therefore, GST underneath the seasonal surface covers can be a good indicator of changes to and general condition of ground thermal regime in the study area. The calculated $\mathrm{TDD}_{\mathrm{s}}$ and $\mathrm{FDD}_{\mathrm{s}}$ since 2011 indicate that GST increased continuously in both thawing and freezing seasons over the last seven years, resulting in greater heat penetration to deeper ground (Figure 3). The seasonal snow cover, which typically lasts from November to March at the hydro-climatic station, showed a mean $\mathrm{n}_{\mathrm{f}}$ value of 0.5 when the mean snow depth was $20 \mathrm{~cm}$ between winters 2011-2012 and 2016-2017. However, winter 2017-2018 had an unusual thick snow cover, significantly insulating the heat flow between the atmosphere and ground surface. The mean $\mathrm{n}_{\mathrm{f}}$ value can be deemed relatively 
consistent across the Sugnugur Valley because our snow field measurements at various elevations did not show any considerable differences in snow depth [28] (Table S2, Supplementary Materials). We hypothesize that the combination of the warmest thawing season 2017 (Figure 3) and the following warmest freezing season due to the thick snowpack may have considerably deepened the active layer and triggered permafrost degradation in the region.

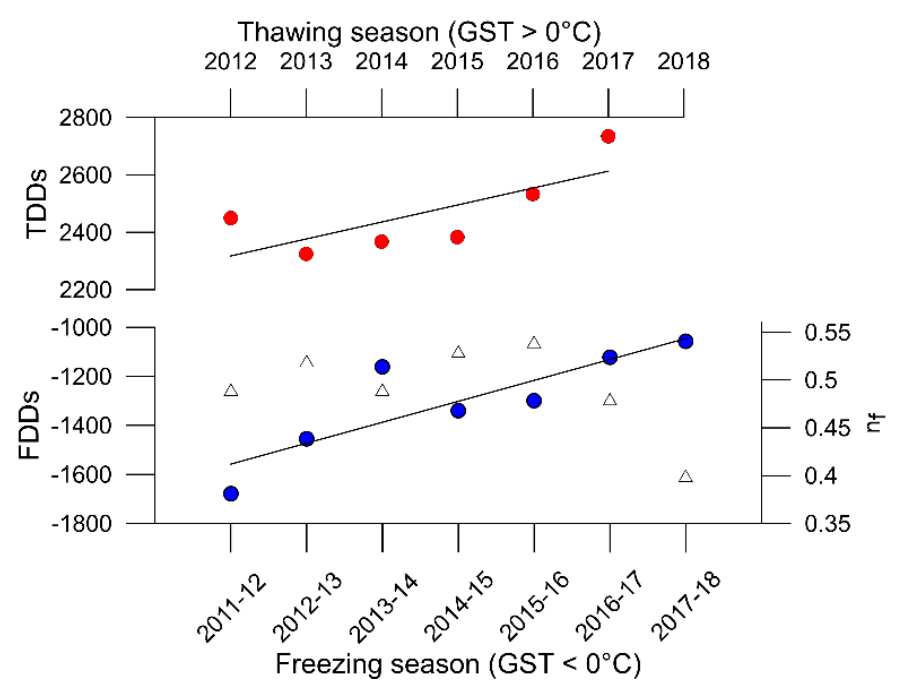

Figure 3. Observed surface thawing $\left(\mathrm{TDD}_{\mathrm{s}}\right)$ and freezing $\left(\mathrm{FDD}_{\mathrm{s}}\right)$ degree-days and the insulating effect of snow $\left(\mathrm{n}_{\mathrm{f}}\right)$ (triangles) at the hydro-climatic station since 2011. GST represents the ground surface temperature.

When the thawing season starts after snowmelt, the overlaying organic layer or vegetation cover acts as an insulating material and prevents the ground surface from summer heating, thus reducing the $\mathrm{TDD}_{\mathrm{s}}$ and favoring permafrost presence under the thick organic moss layer. The measured biomass and $K$ showed high variability across the valley transects, with significant differences between SBF and UBF sites (Figure $4 a, b)$.
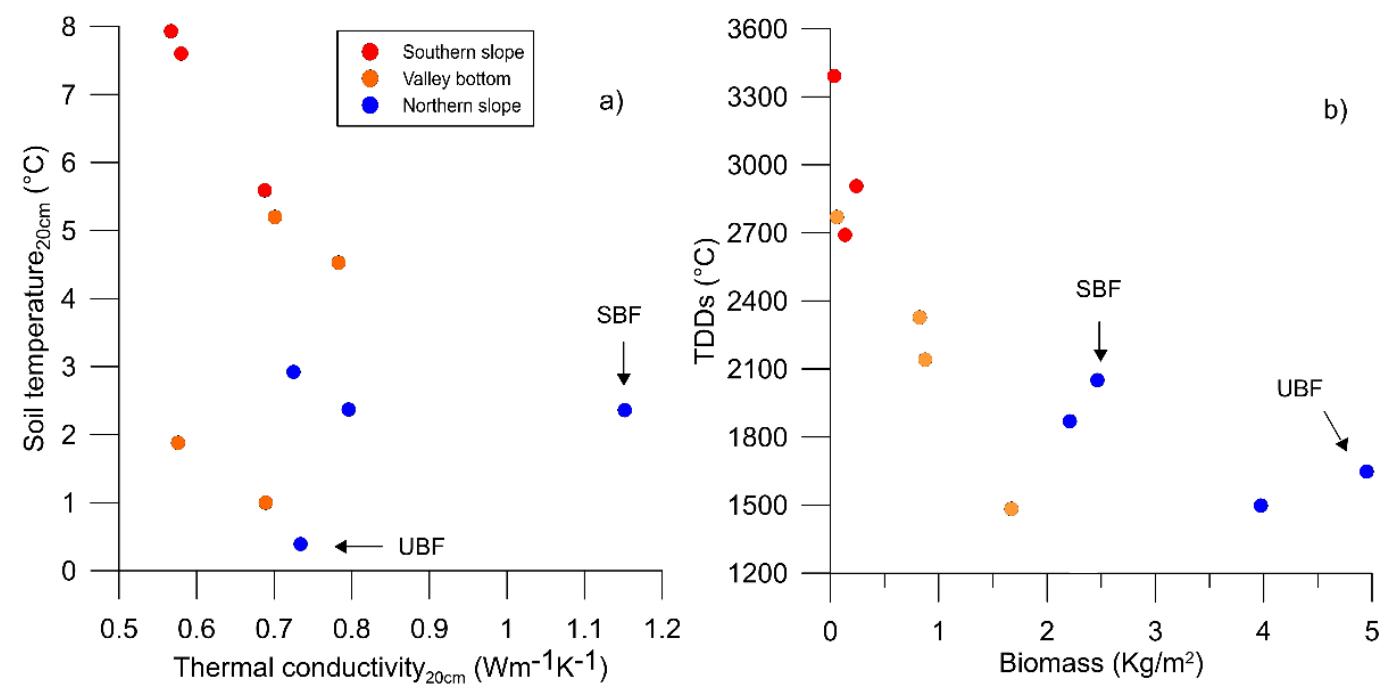

Figure 4. Variability of thermal conductivity (at 20-cm depth) in relation to ground temperature at corresponding depth (a) and biomass, and their relationship with calculated surface thawing degree days $\left(\mathrm{TDD}_{\mathrm{s}}\right.$ ) for 2016-2017 (b).

The weight of the combusted organic layer ( $\sim 4 \mathrm{~cm}$ thick) under SBF was one-half of that $(\sim 15 \mathrm{~cm}$ thick) under UBF. Since the thermal conductivity of the organic layer is less than underlying mineral 
soil, its loss increased heat transfer to the ground surface under SBF. An additional effect of the reduced organic layer is the absorption of less precipitation water and increased soil moisture in the upper soil horizon, resulting in a greater downward heat flow $[2,15,21,41]$. Therefore, post-fire soil moisture increase in the upper soil horizon and increased ground flux are the major factors affecting the hydrothermal dynamics of the active layer, as well as the underlain permafrost [42]. Lastly, we conclude that the $\mathrm{TDD}_{\mathrm{s}}$ difference between the slopes could be as high as $\sim 1000{ }^{\circ} \mathrm{C}$ within a short horizontal distance or mean ground surface temperature (MGST) of $3-4{ }^{\circ} \mathrm{C}$, indicating that the thick moss layer on the forested north-facing slope may favor permafrost existence (Table 2). However, the continuously increasing GST since 2011 suggests that permafrost in this region might be degrading, especially in areas where wildfire affected the ground thermal regime.

\subsection{Response of Ground Hydrothermal Regime to Climtaic Variability}

Although our observation period in the pits was relatively short and not sufficient to produce a long-term analysis, it included contrasting climatic variables such as a drought event in summer 2017 and an infrequent thick snow cover in the following winter 2017-2018. Table 3 summarizes the climatic variabilities at the hydro-climatic station and the pits. According to the observed data at the hydro-climatic station, the first half of the thawing season 2017 (year 2016-2017) was characterized as very dry with only $65 \mathrm{~mm}$ of rainfall and several wildfire occurrences in the region, while the ones in both 2016 and 2018 had $\sim 160 \mathrm{~mm}$. The overall $\mathrm{TDD}_{\mathrm{s}}$ at the SBF site was 70-100 ${ }^{\circ} \mathrm{C}$ higher than the previous and the following thawing seasons.

Table 3. Overview of the climatic variability during the period of soil temperature and moisture observations in the pits. The hydrological years include complete freezing and thawing seasons (na-not available; nc-not complete).

\begin{tabular}{|c|c|c|c|c|c|c|c|c|c|}
\hline \multirow{2}{*}{ Year } & \multirow[b]{2}{*}{$\operatorname{TDD}_{\mathrm{a}}\left({ }^{\circ} \mathrm{C}\right)$} & \multicolumn{5}{|c|}{ Hydro-Climatic Station } & \multicolumn{3}{|c|}{ UBF $\left({ }^{\mathrm{u}}\right)$ and SBF $\left(^{\mathrm{s}}\right)$ Sites } \\
\hline & & $\operatorname{FDD}_{\mathrm{a}}\left({ }^{\circ} \mathrm{C}\right)$ & $n_{f}(-)$ & $\operatorname{ASD}(\mathrm{cm})$ & SCD (day) & Prec. $(\mathrm{mm})$ & $\mathrm{FDD}_{\mathrm{s}}\left({ }^{\circ} \mathrm{C}\right)$ & $\operatorname{TDD}_{\mathrm{s}}\left({ }^{\circ} \mathrm{C}\right)$ & $\operatorname{ASD}(\mathrm{cm})$ \\
\hline $2015-2016$ & 2240 & -2604 & 0.5 & 18 & 127 & 382 & $\mathrm{na}^{\mathrm{u}} / \mathrm{nc}^{\mathrm{s}}$ & $\mathrm{nc}^{\mathrm{u}} / 1604^{\mathrm{s}}$ & na \\
\hline 2016-2017 & 2288 & -2459 & 0.46 & 22 & 141 & 323 & $-1318^{\mathrm{u}} /-1140^{\mathrm{s}}$ & $1402^{\mathrm{u}} / 1715^{\mathrm{s}}$ & $25^{\mathrm{u}} / 27^{\mathrm{s}}$ \\
\hline $2017-2018$ & $\mathrm{nc}$ & -2687 & 0.4 & 31 & 123 & $>423$ & $-1166^{\mathrm{u}} /-913^{\mathrm{s}}$ & $1525^{\mathrm{u}} / 1643^{\mathrm{s}}$ & $35^{\mathrm{u}} / 35^{\mathrm{s}}$ \\
\hline 2018-2019 & na & na & na & 5 & na & na & $-1299^{\mathrm{u}} /-1006^{\mathrm{s}}$ & $n c^{\mathrm{u}} / \mathrm{nc}^{\mathrm{s}}$ & $19^{\mathrm{u}} / 26^{\mathrm{s}}$ \\
\hline
\end{tabular}

In winter 2017-2018, the snow depth was greater by $\sim 10 \mathrm{~cm}$ than the average of the previous five years (Figure S1). In addition to the increased heat insulation effect of this thick snowpack, its timing was also the shortest since 2012, as indicated by snow cover duration (SCD), resulting in a prolonged thawing season and increased ground temperature at all depths. The snow onset was delayed by $\sim 10$ days and melt date was earlier by $\sim 10$ days in the freezing season 2017-2018 compared to previous years. As a consequence of the short freezing season with thick snow cover, $\mathrm{FDD}_{\mathrm{s}}$ at the hydro-climatic station were the lowest (warmest) compared to previous years (Figure 3). This is also seen from the pit data; $F_{D D}$ 2017-2018 was warmer than both the previous and the following winters by $150{ }^{\circ} \mathrm{C}$ and $130{ }^{\circ} \mathrm{C}$, respectively.

When the air temperature rises above $0{ }^{\circ} \mathrm{C}$ and snowmelt occurs, the ground thawing process begins in the active layer with a time delay depending on depth, soil texture, available energy, and ice or unfrozen water contents [43]. The combination of the drought event following the thick snow cover increased the ground temperature and active layer thickness in the region. This is apparent through the long thawing period with drastic temperature increase at both UBF and SBF sites during the thawing season 2018 (Figure 5a,b). For instance, the thawing process at $120 \mathrm{~cm}$ began about a month earlier from 23 July in 2018 compared to 15 August in 2017 under UBF. At this depth, the maximum soil temperature was $2.4^{\circ} \mathrm{C}$ (on 25 August 2018) or $1.8^{\circ} \mathrm{C}$ higher than that in 2016-2017.

For the SBF site, we took the hydrological year 2015-2016 as a reference year and observed a similar drastic temperature increase in the year 2017-2018. Furthermore, regardless of the prolonged thawing season 2018, the shallow snow cover in winter 2018-2019, with high density (Table S2) resulted in a lower insulation effect, which allowed the soil at 290 -cm depth to refreeze up to $-0.5^{\circ} \mathrm{C}$ in the SBF 
for the first time over the observation period. Soil temperatures at this depth did not drop below $0{ }^{\circ} \mathrm{C}$ (zero curtain) for three of the last four years.
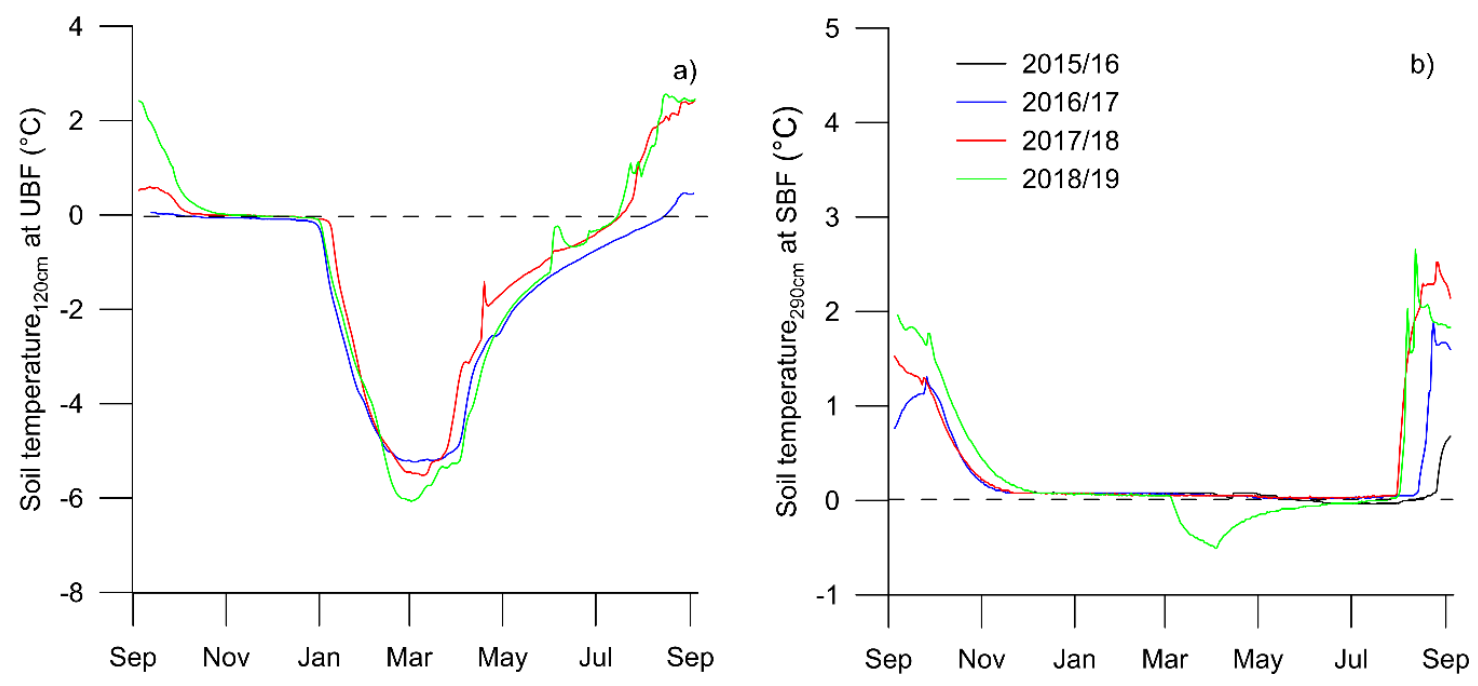

Figure 5. Temperature changes at the frost table under unburned (UBF) and severely burned (SBF) forest. The dashed line at $0{ }^{\circ} \mathrm{C}$ separates the soil freeze and thaw.

The measured ASD and snow water equivalent (SWE) were slightly lower in the unburned forest than the burned forest due to probably the interception effect of forest canopy (Table S2). Once the snow cover melted completely, the ground heat flux, which is intensified by the snowmelt water, increased the soil-thawing rate from 0.04 to $0.5^{\circ} \mathrm{C} /$ day, as well as the unfrozen water content, within a few days at UBF site [44].

Unfrozen water content in frozen soil over permafrost regions is a well-known phenomenon during the freezing season, and it typically occurs within fine-grained clay soils with small pores [45,46]. We observed a relatively stable unfrozen water content $\left(0.2-0.27 \mathrm{~m}^{3} / \mathrm{m}^{3}\right)$ in frozen soils at $\geq 30-\mathrm{cm}$ depths when temperature was up to $-7.5^{\circ} \mathrm{C}$. When soil temperature dropped below $-0.6{ }^{\circ} \mathrm{C}$, the amount of unfrozen water content stabilized until the soil began to thaw, which is similar to that in the southern Yukon Territory, Canada [43]. During the intensive phase change period from freeze to thaw, or thaw to refreeze when $-0.6{ }^{\circ} \mathrm{C}<\mathrm{T}<0{ }^{\circ} \mathrm{C}$, unfrozen water content increases or decreases drastically. Irrespective of the dry summer months in 2017, the initial SWC prior to soil freeze was identical in the lower soil layer, compared to previous year. This could be addressed to the heavy rainfall occurrences in late summer 2017.

To see the overall impact of the extreme weather events on the hydrothermal regime in the active layer, it was possible to compare the soil temperature and moisture data of 2017-2018 (covering both complete thawing and freezing seasons) to 2016-2017. The mean annual ground temperature (MAGT) for 2017-2018 showed a significant increase throughout the soil profile at the UBF site (Figure 6a). Figure $6 \mathrm{~b}$ shows the comparison of changes in unfrozen water content during the phase change periods in springs 2017 and 2018 since the snowmelt began. The higher unfrozen water content in 2018 was probably due to the increased snowmelt water that infiltrated the ground.

\subsection{Impact of Wildfire on Active Layer Dynamics}

Due to the absence of pre-fire data, the only possibility to see the hydrothermal changes in the active layer was to compare the observed temperature and moisture at SBF to those at UBF, taking it as a control site. We argue that this can be reasonable because the sites are adjacently located on the same north-facing slope, assuming the pre-fire condition was similar. The magnitude of burn severity as indicated by the reduction of biomass and a higher thermal conductivity by $0.42 \mathrm{~W} \cdot \mathrm{m}^{-1} \cdot \mathrm{K}^{-1}$ at $\mathrm{SBF}$, compared to UBF, were strong predictors of an increase in ground temperature. The comparison 
of MAGT at 1-m depth between SBF, MBF, and UBF sites confirmed a clear temperature difference with a burn gradient, showing the warmest temperature at SBF in both freezing and thawing seasons (Figure 7a).
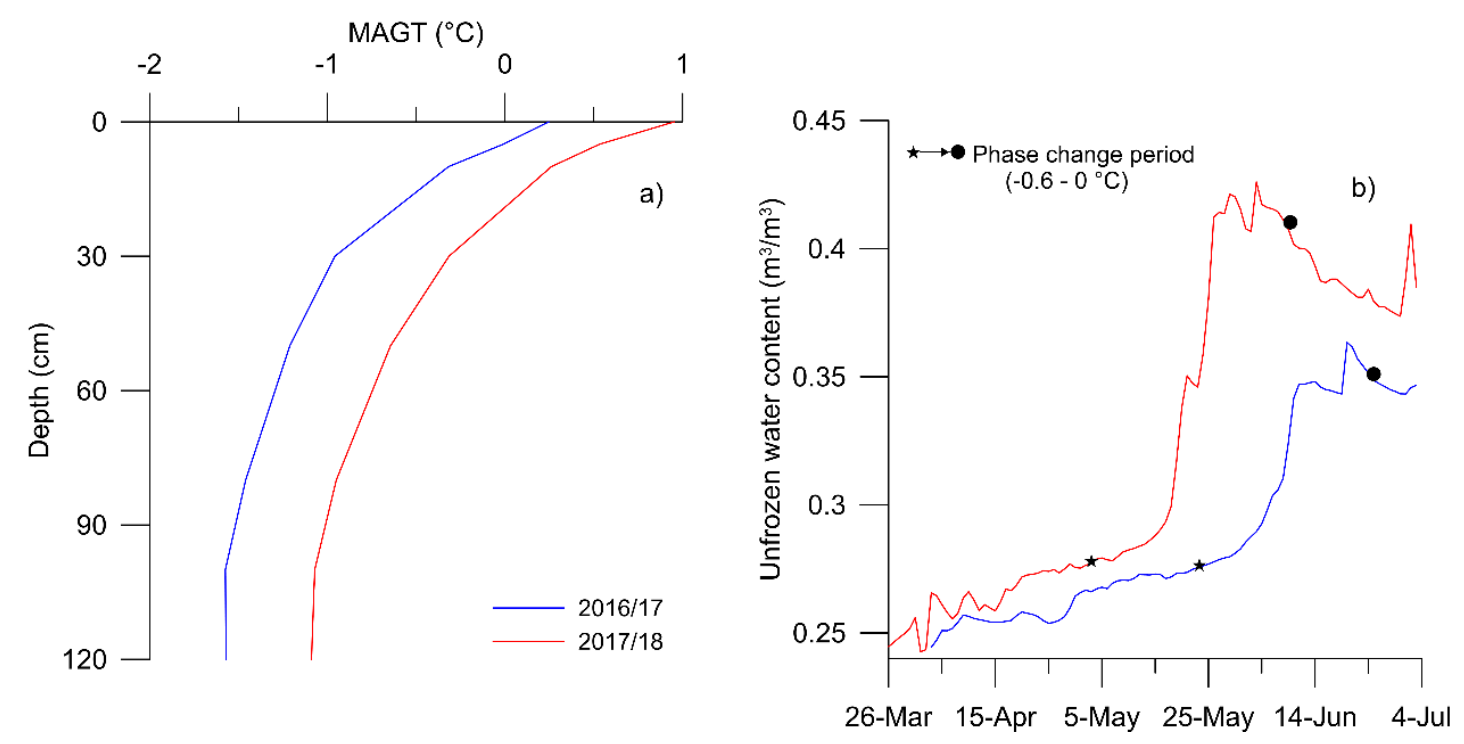

Figure 6. Changes in mean annual ground temperature (MAGT) between the hydrological years 2016-2017 and 2017-2018 (a) and water content in frozen soil during the phase change periods in 2017 and 2018 after snowmelt at the UBF site (b).
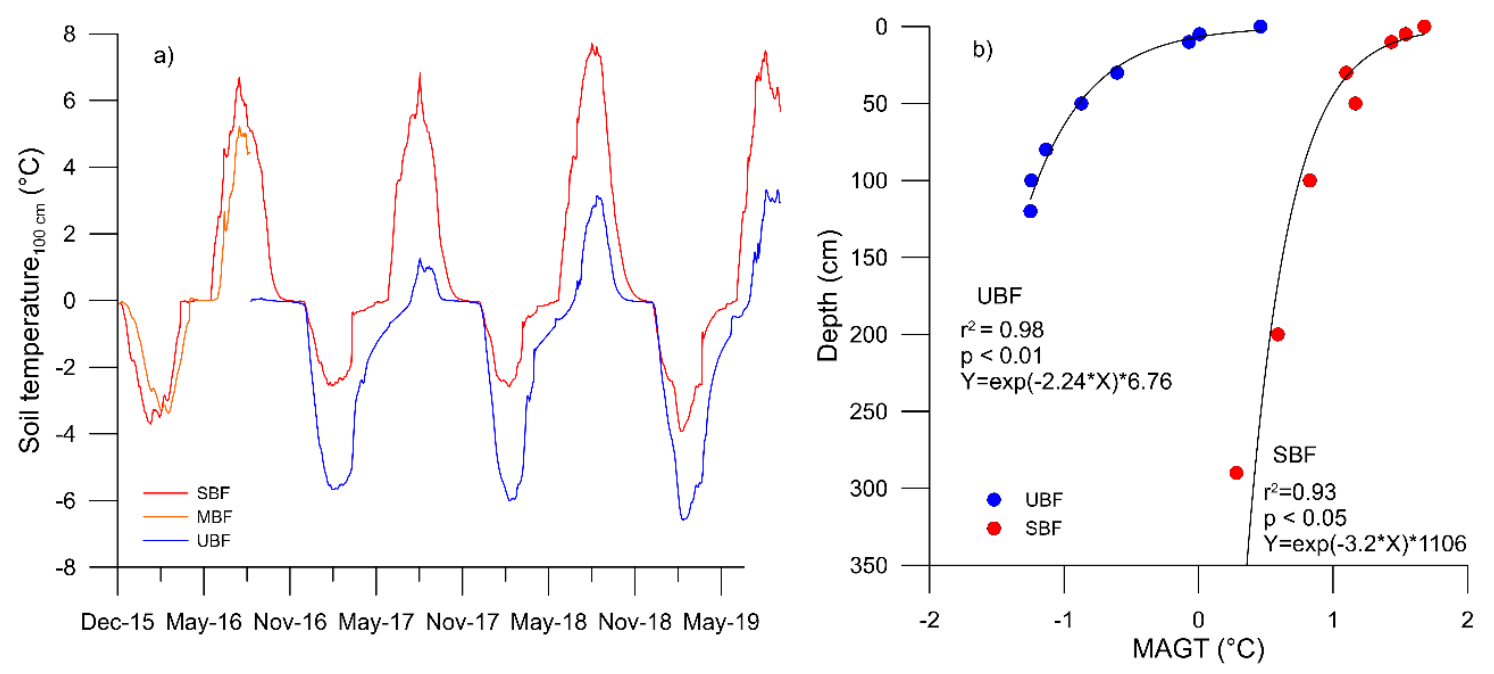

Figure 7. Observed daily ground temperature at 1-m depth under severely burned (SBF), moderate burned (MBF), and unburned (UBF) forests (a). Mean temperature profile at SBF compared to UBF (b).

Moreover, it is worth noting that the temperature increase at SBF was not linear throughout the soil profile, revealing a greater increase in the lower soil horizons, relative to UBF (Figure S2, Supplementary Materials). This can be a result of the reduced downward water infiltration due to the reduced organic layer, which functions as an absorbent material of rainfall and snowmelt water, and then gradually transfers it later into the ground. Thus, it is expected that the combusted organic layer absorbs less water in SBF and causes quick runoff over the mineral soil and sediment transport. Overall, the observed MAGT during the observation period under UBF with natural condition showed a non-linear temperature decrease with depth $\left(r^{2}=0.98, p<0.001\right)$ while that under SBF revealed a somewhat disturbed temperature rate $\left(r^{2}=0.93, p<0.05\right)$ (Figure $7 \mathrm{~b}$ ). This is probably due to the loss of the organic layer modifying the moisture regimes, as well as the soil heterogeneity. 
Previous studies, which were conducted in summer 2012 on the same slope, found higher SWC and quick flow in the upper soil of SBF after intensive rainfall events, whereas lateral subsurface flow which recharges the Sugnugur river during dry season is common with relatively lower SWC in the upper soil of UBF $[18,30]$. The year-round mean liquid SWC, including unfrozen water, increases with depth at UBF site (Figure S3, Supplementary Materials). The observed SWC at 10-cm depth at the SBF site was considerably greater by $0.16 \mathrm{~m}^{3} / \mathrm{m}^{3}$, while that at $30 \mathrm{~cm}$ was much lower by $0.2 \mathrm{~m}^{3} / \mathrm{m}^{3}$ compared to the UBF site for summer 2017 (Figure 8a). This implies that a reduced water infiltration into the deeper soil layers can be expected in SBF, which is in a good agreement with previous findings [18]. In fact, the variation of SWC at 30-cm depth at SBF was smaller than that at UBF, inferring the disturbance of water infiltration from the upper soil. A possible reason for that could be the existence of a fire-induced hydrophobic layer, which restricts the water infiltration and unbalances the SWC in the soil profile [23].
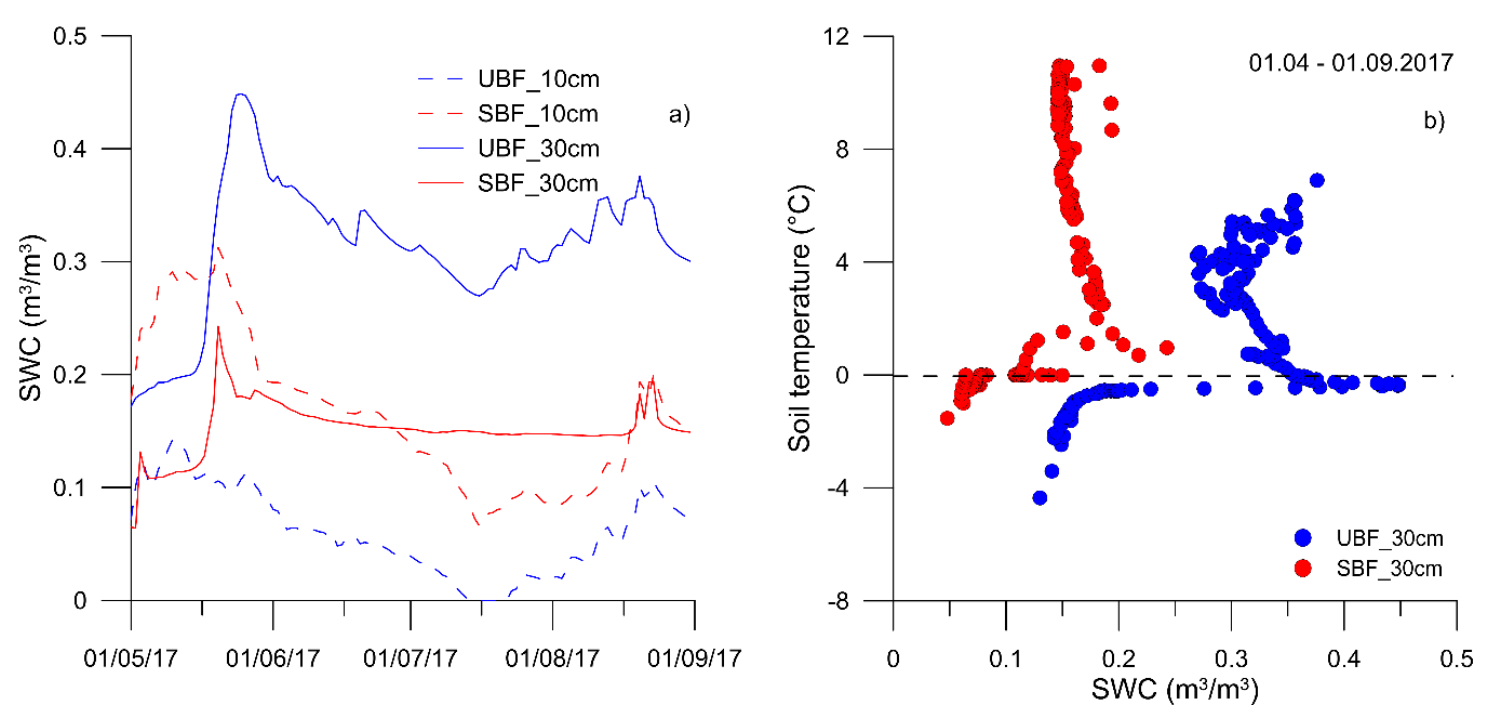

Figure 8. Soil water content (SWC) at 10- and 30-cm depths at UBF and SBF sites during the thawing season 2017 (a) and its relationship with soil temperature (b).

To see the effect of infiltrated water on ground temperature during thawing season, we plotted the observed SWC against temperature at 30-cm depths at both sites for the thawing season 2017 (Figure 8b). The result indicates that the infiltrated rainwater slowed down the rate of temperature increase at UBF site due to the increased latent heat energy required for warming the wet soil. In contrast, there was a minor effect of infiltrated water on soil warming at the SBF site, causing soil warming to continue throughout the thawing season.

The observed minimum temperature was close to $0{ }^{\circ} \mathrm{C}$ while the maximum temperature was $+2.5^{\circ} \mathrm{C}$ (at $290 \mathrm{~cm}$ depth) at the SBF site over the study period. On the other hand, temperatures at $120-\mathrm{cm}$ depth at the UBF site indicated permafrost presence in deeper ground with a minimum temperature of $-6^{\circ} \mathrm{C}$ and maximum temperature of $+2.4^{\circ} \mathrm{C}$ (Figure 9). This maximum temperature indicates that thawing depths exist below our deepest observational depths at both sites.

The calculated thawing depths with Stefan's model were $1.3 \mathrm{~m}$ for UBF and $\sim 2.1 \mathrm{~m}$ for SBF (Table 4). The deeper thawing depth in SBF, relative to UBF, can be a result of multiple factors, including the loss of organic layer, higher incoming solar radiation, higher $K$, relatively thicker snow depth, and the reduced SWC. Based on the observed data, SWC and $K$ were assumed to be $0.3 \mathrm{~m}^{3} / \mathrm{m}^{3}$ and $0.73 \mathrm{~W} \cdot \mathrm{m}^{-1} \cdot \mathrm{K}^{-1}$ for UBF in the model, and $0.2 \mathrm{~m}^{3} / \mathrm{m}^{3}$ and $1.15 \mathrm{~W} \cdot \mathrm{m}^{-1} \cdot \mathrm{K}^{-1}$ for SBF. The model result was similar to that observed in UBF, whereas it was underestimated by $\sim 0.8 \mathrm{~m}$ in SBF. This difference could be attributed to the increased heat penetration during and after the wildfire, altering the thermodynamic equilibrium condition. 

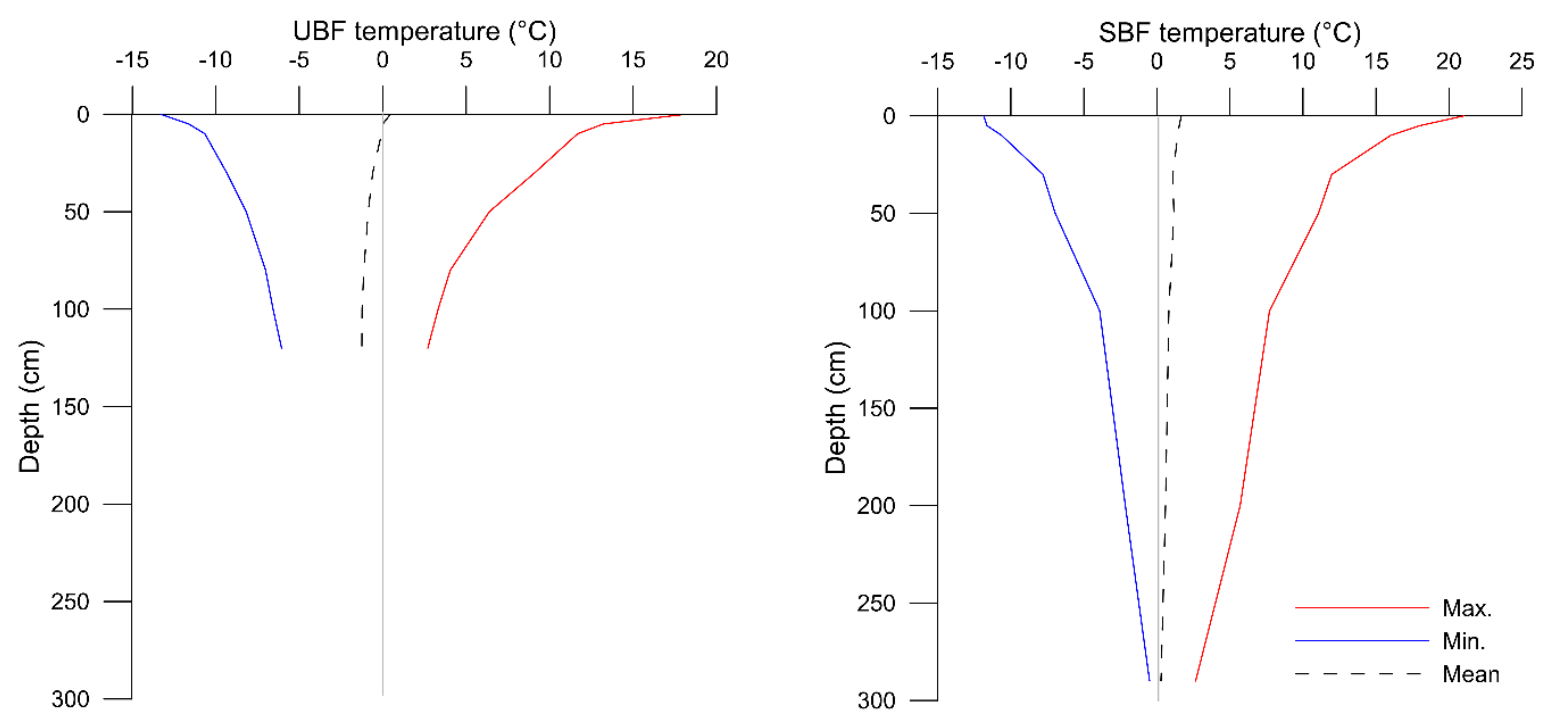

Figure 9. Annual maximum, minimum, and mean temperatures at the unburned (UBF) and severely burned (SBF) forest sites between 2016 and 2018.

Table 4. The calculated thawing depth (in meters) using Stefan's heat transfer model.

\begin{tabular}{ccccc}
\hline Site & $\mathbf{2 0 1 6}$ & $\mathbf{2 0 1 7}$ & $\mathbf{2 0 1 8}$ & Observed \\
\hline UBF & - & 1.3 & 1.3 & $>1.2$ \\
\hline SBF & 2.1 & 2.2 & 2.1 & $\sim 2.9$ \\
\hline
\end{tabular}

Assuming the pre-fire condition at SBF was similar to UBF, the wildfire deepened the thawing depth over the last decade, or it may even have led to complete permafrost loss. Disequilibrium freezing and thawing can occur with sudden temperature change [9], such as wildfire. However, drawing a strong conclusion on the existence of permafrost below the increased thawing depth requires further investigation. To improve the result of Stefan's vertical heat transfer model, it is necessary to understand the horizontal heat transfer and water movement within the affected soil profile in SBF and the active layer in UBF. Thus, the calculated thawing depth in SBF requires equation modifications that accommodate soil layering, heat capacity, and the thermal conductivity of partially frozen soils. These uncertainties could be addressed via laboratory experiments to mathematically represent the complex soil thermodynamic process. Future work is warranted to conduct a geophysical research over SBF, $\mathrm{MBF}$, and UBF sites to validate the depth to permafrost table, to determine the thickness of permafrost thaw, and to excavate additional permafrost monitoring pits to better represent spatial variability.

The continuously increasing GST (Figure 3) and the barely visible vegetation recovery, which is not sufficient to insulate the ground beneath [47], indicate that the process of active layer thickening and permafrost degradation will continue further. Lastly, given that about $30 \%$ of the forest is affected by wildfire, it is almost sure that the ground hydrothermal regime was changed extensively in this headwater stream area.

\section{Conclusions}

The current study is a continuation of our previous studies, which highlighted the effect of wildfire on the runoff generation process, soil moisture dynamics, and evapotranspiration in the Khentii Mountains of northern Mongolia. We present a preliminary result of the dual effect of wildfire and climate change on permafrost stability. Furthermore, the investigation is aimed at understanding the spatial variability of GST and post-fire hydrothermal changes in this data-scarce region. 
We conclude that both surface freezing and thawing degree-days continuously increased since 2011, in which a drought and infrequent thick snow cover events played crucial roles. As such extreme weather events are projected to occur more frequently in the region due to changing climate, the ground temperature may increase, leading to permafrost degradation in the future. The observed iButton temperature measurements showed a high MGST variability $\left(3-4{ }^{\circ} \mathrm{C}\right)$ between north- and south-facing slopes because of distinct surface characteristics within a short horizontal distance. However, permafrost, which typically exists on the north-facing slopes covered by boreal forest with a thick organic layer underneath, may have thawed significantly in 30\% of the Sugnugur catchment, where wildfires altered the hydrothermal regime of the active layer and triggered permafrost loss. Although our observation period in the pits was relatively short, we conclude that permafrost is very vulnerable to climate change and fire-initiated surface cover disturbance in this discontinuous permafrost region with a semi-arid climate. Therefore, special attention should be paid to further investigations on ecosystem resilience and climate change mitigation in this region, as well as other regions characterized by discontinuous permafrost and a semi-arid climate.

Supplementary Materials: The following are available online at http://www.mdpi.com/2073-4433/11/2/155/s1, Figure S1: Observed annual air temperature and accumulated snow depth, Figure S2: Mean temperature difference between burned and unburned forests, Figure S3: Observed liquid soil water content at unburned forest site, Table S1: Soil texture and water content, Table S2: Overview of snow field measurements.

Author Contributions: Munkhdavaa Munkhjargal (M.M.) analyzed the data, carried out the fieldwork, and wrote the manuscript. Gansukh Yadamsuren (G.Y.) contributed to the fieldwork and data analysis. Lucas Menzel (L.M.) provided climatic data, supported the fieldwork, and supervised the study. Jambaljav Yamkhin (J.Y.) carried out the snow measurements and provided crucial suggestions to improve the manuscript. All authors have read and agreed to the published version of the manuscript.

Funding: This research received no external funding

Acknowledgments: Munkhdavaa Munkhjargal received funding from the Federal Ministry of Education and Research (BMBF) through the German Academic Exchange Service (DAAD) during the preparation of this manuscript. We acknowledge financial support by Kurt-Hiehle-Stiftung, Institute of Geography, Heidelberg University.

Conflicts of Interest: The authors declare no conflicts of interest.

\section{References}

1. Osterkamp, T.E.; Romanovsky, V.E. Evidence for Warming and Thawing of Discontinuous Permafrost in Alaska. Permafr. Periglac. Process. 1999, 10, 17-37. [CrossRef]

2. Yoshikawa, K.; Bolton, W.R.; Romanovsky, V.E.; Fukuda, M.; Hinzman, L.D. Impacts of wildfire on the permafrost in the boreal forests of Interior Alaska. J. Geophys. Res. 2002, 108, D18148. [CrossRef]

3. Tchebakova, N.M.; Parfenova, E.; Soja, A.J. The effects of climate, permafrost and fire on vegetation change in Siberia in a changing climate. Environ. Res. Lett. 2009, 4, 045013. [CrossRef]

4. Ishikawa, M.; Jambaljav, Y.; Dashtseren, A.; Sharkhuu, N.; Davaa, G.; Ijima, Y.; Baatarbileg, N.; Yoshikawa, K. Thermal states, responsiveness and degradation of marginal permafrost in Mongolia. Permafr. Periglac. Process. 2018, 29, 271-282. [CrossRef]

5. Biskaborn, B.K.; Smith, S.L.; Noetzli, J.; Matthes, H.; Viera, G.; Streletskiy, D.A.; Schoeneich, P.; Romanovsky, V.E.; Lewkowicz, A.G.; Abramov, A.; et al. Permafrost is warming at a global scale. Nat. Commun. 2019, 10, 264. [CrossRef] [PubMed]

6. Mongolian Second Assessment Report on Climate Change (MARCC); Ministry of Environment and Green Development: Ulaanbaatar, Mongolia, 2014.

7. Hansen, J.; Ruedy, R.; Sato, M.; Lo, K. Global surface temperature change. Rev. Geophys. 2010, 48, RG4004. [CrossRef]

8. Smith, M.W.; Riseborough, D.W. Climate and the Limits of Permafrost: A Zonal Analysis. Permafr. Periglac. Process. 2002, 13, 1-15. [CrossRef]

9. Walvoord, M.A.; Kurylyk, B.L. Hydrologic Impacts of Thawing Permafrost-A Review. Vadose Zone J. 2016, 15, 1-20. [CrossRef] 
10. Bartsch, A.; Balzter, H.; George, C. The influence of regional surface soil moisture anomalies on forest fires in Siberia observed from satellites. Environ. Res. Lett. 2009, 4, 045021. [CrossRef]

11. Jafarov, E.E.; Romanovsky, V.E.; Genet, H.; McGuire, A.D.; Marchenko, S.S. The effects of fire on the thermal stability of permafrost in lowland and upland black spruce forests of interior Alaska in a changing climate. Environ. Res. Lett. 2013, 8, 35030. [CrossRef]

12. Gibson, C.M.; Chasmer, L.E.; Thompson, D.K.; Quinton, W.L.; Flannigan, M.D.; Olefeldt, D. Wildfire as a major driver of recent permafrost thaw in boreal peatlands. Nature Commun. 2018, 9, 3041. [CrossRef] [PubMed]

13. Connon, R.; Devoie, É.; Hayashi, M.; Veness, T.; Quinton, W. The influence of shallow taliks on permafrost thaw and active layer dynamics in subarctic Canada. J. Geophys. Res. Earth Surface 2018, 123, 281-297. [CrossRef]

14. Brown, D.R.N.; Jorgenson, M.T.; Douglas, T.A.; Romanovsky, V.E.; Kielland, K.; Hiemstra, C.; Euskirchen, E.S.; Ruess, R.W. Interactive effects of wildfire and climate on permafrost degradation in Alaskan lowland forests. J. Geophys. Res. Biogeosciences 2015, 120, 1619-1637. [CrossRef]

15. Jiang, Y.; Rocha, A.V.; Donnell, J.A.O.; Drysdale, J.A.; Rastetter, E.B.; Shaver, G.R.; Zhuang, Q.J. Contrasting soil thermal responses to fire in Alaskan tundra and boreal forest. Geophys. Res. Earth Surface 2015, 120, 363-378. [CrossRef]

16. Yi, S.; McGuire, A.D.; Harden, J.; Kasischke, E.; Manies, K.; Hinzman, L.; Liljedahl, A.; Randerson, J.; Liu, H.; Romanovsky, V.; et al. Interactions between soil thermal and hydrological dynamics in the response of Alaska ecosystems to fire disturbance. J. Geophys. Res. 2009, 114, G02015. [CrossRef]

17. Hayashi, M.; Goeller, N.; Quinton, W.L.; Wright, N. A simple heat-conduction method for simulating the frost-table depth in hydrological models. Hydrol. Process. 2007, 21, 2610-2622. [CrossRef]

18. Kopp, B.J.; Lange, J.; Menzel, L. Effects of wildfire on runoff generating processes in northern Mongolia. Reg. Environ. Change 2016, 17, 1951-1963. [CrossRef]

19. Alexander, H.D.; Natali, S.M.; Loranty, M.M.; Ludwig, S.M.; Spektor, V.V.; Davydov, S.; Zimov, N.; Trujillo, I.; Mack, M.C. Impacts of increased soil burn severity on larch forest regeneration on permafrost soils of far northeastern Siberia. For. Ecol. Manag. 2018, 417, 144-153. [CrossRef]

20. Ebel, B.A.; Moody, J.A.; Martin, D.A. Hydrologic conditions controlling runoff generation immediately after wildfire. Water Resour. Res. 2012, 48, W03529. [CrossRef]

21. Nossov, D.R.; Jorgenson, M.T.; Kielland, K.; Kanevskiy, M. Edaphic and microclimatic controls over permafrost response to fire in interior Alaska. Environ. Res. Lett. 2013, 8, 35013. [CrossRef]

22. Semenova, O.; Lebedeva, L.; Volkova, N.; Korenev, I.; Forkel, M.; Eberle, J.; Urban, M. Detecting immediate wildfire impact on runoff in a poorly-gauged mountainous permafrost basin. Hydrolog. Sci. J. 2015, 60, 1225-1241. [CrossRef]

23. Debano, L.F. The role of fire and soil heating on water repellency in wildland environments: A review. J. Hydrol. 2000, 231-232, 195-206. [CrossRef]

24. Wondzell, S.M.; King, J.G. Postfire erosional processes in the Pacific Northwest and Rocky Mountain regions. Forest Ecol. Manag 2003, 178, 75-87. [CrossRef]

25. Bodi, M.B.; Doerr, S.H.; Cerdà, A.; Mataix-solera, J. Effects of a layer of vegetative ash layer on wettable and water repellent soil hydrology. Geoderma 2012, 191, 14-23. [CrossRef]

26. Ishikawa, M.; Zhang, Y.; Kadota, T.; Ohata, T. Hydrothermal regimes of the active layer. Water Resour. Res. 2006, 42, W04401. [CrossRef]

27. Dashtseren, A.; Ishikawa, M.; Iijima, Y.; Yamkhin, J. Temperature regimes of the active layer and seasonally frozen ground under a forest-steppe mosaic, Mongolia. Permafr. Periglac. Process. 2014, 25, 295-306. [CrossRef]

28. Munkhjargal, M.; Groos, S.; Pan, C.G.; Yadamsuren, G.; Yamkhin, J.; Menzel, L. Multi-source based spatio-temporal distribution of snow in a semi-arid headwater catchment of Northern Mongolia. Geosciences 2019, 9, 53. [CrossRef]

29. Munkhjargal, M.; Menzel, L. Estimating daily average net radiation in Northern Mongolia. Geograf. Ann. A 2019, 10, 177-194. [CrossRef]

30. Lange, J.; Kopp, B.J.; Bents, M.; Menzel, L. Tracing variability of run-off generation in mountainous permafrost of semi-arid north-eastern Mongolia. Hydrol. Process. 2015, 29, 1046-1055. [CrossRef] 
31. Menzel, L.; Hofmann, J.; Ibisch, R. Studies of water and mass fluxes to provide a basis for an Integrated Water Resources Management (IWRM) in the catchment of the River Kharaa in Mongolia. Hydrologie und Wasserbewirtschaftungy 2011, 55, 88-103.

32. Shur, Y.L.; Jorgenson, M.T. Patterns of permafrost and degradation in relation to climate and ecosystems. Permafr. Periglac. Process. 2007, 18,7-19. [CrossRef]

33. Kopp, B.J.; Minderlein, S.; Menzel, L. Soil Moisture Dynamics in a Mountainous Headwater Area in the Discontinuous Permafrost Zone of northern Mongolia. Arct. Antarct. Alp. Res. 2014, 46, 459-470. [CrossRef]

34. Gruber, S. The Cryosphere Derivation and analysis of a high-resolution estimate of global permafrost zonation. Cryosphere 2010, 6, 221-233. [CrossRef]

35. Minderlein, S.; Menzel, L. Evapotranspiration and energy balance dynamics of a semi-arid mountainous steppe and shrubland site in Northern Mongolia. Environ. Earth Sci. 2014, 73, 593-609. [CrossRef]

36. Stefan, J. Über die Theorie der Eisbildung, insbesondere über die Eisbildung im Polarmee. Ann. Phys. Chem. 1891, 278, 269-286. [CrossRef]

37. Groisman, P.V.; Blyakharchuk, T.A.; Chernokulsky, A.V.; Arzhanov, M.M.; Marchesini, L.B.; Bogdanova, E.G.; Borzenkova, I.; Bulygina, O.N.; Karpenko, A.A.; Karpenko, L.V.; et al. Climate changes in Siberia. In Regional Environmental Changes in Siberia and Their Global Consequences; Groisman, P., Gutman, G., Eds.; Springer Environmental Science and Engineering, Springer: Dordrecht, The Netherlands, 2013; pp. 57-109. ISBN 978-94-007-4569-8.

38. Ponomarev, E.I.; Kharuk, V.I.; Ranson, K.J. Wildfires dynamics in siberian larch forests. Forests 2016, 7, 125. [CrossRef]

39. Kukavskaya, E.A.; Buryak, L.V.; Shvetsov, E.G.; Conard, S.G.; Kalenskaya, O.P. The impact of increasing fire frequency on forest transformations in southern Siberia. Forest Ecol. Manag. 2016, 382, 225-235. [CrossRef]

40. Kharuk, V.I.; Ranson, K.J.; Dvinskaya, M.L.; Im, S.T. Wildfires in northern Siberian larch dominated communities. Environ. Res. Lett. 2011, 6, 045208. [CrossRef]

41. Kasischke, E.S.; Johnstone, J.F. Variation in postfire organic layer thickness in a black spruce forest complex in interior Alaska and its effects on soil temperature and moisture. Can. J. For. Res. 2005, 35, $2164-2177$. [CrossRef]

42. Chambers, S.D.; Beringer, J.; Randerson, J.T.; Chapin III, F.S. Fire effects on net radiation and energy partitioning: Contrasting responses of tundra and boreal forest ecosystems. J. Geophys. Res. Atmos. 2005, 110, D09106. [CrossRef]

43. Quinton, W.L.; Shirazi, T.; Carey, S.K.; Pomeroy, J.W. Soil Water Storage and Active-layer Development in a Sub-alpine Tundra Hillslope, Southern Yukon Territory, Canada. Permafr. Periglac. Process. 2005, 16, 369-382. [CrossRef]

44. Watanabe, K.; Kito, T.; Dun, S.; Wu, J.Q.; Greer, R.C.; Flury, M. Water infiltration into a frozen soil with simultaneous melting of the frozen layer. Vadose Zone 2012, 12. [CrossRef]

45. Romanovsky, V.E.; Osterkamp, T.E. Effects of Unfrozen Water on Heat and Mass Transport Processes in the Active Layer and Permafrost. Permafr. Periglac. Process. 2000, 11, 219-239. [CrossRef]

46. Scherler, M.; Hauck, C.; Hoelzle, M.; Stähli, M.; Völksch, I. Meltwater Infiltration into the Frozen Active Layer at an Alpine Permafrost Site. Permafr. Periglac. Process. 2010, 21, 325-334. [CrossRef]

47. Barret, K.; McGuire, A.D.; Hoy, E.E.; Kasischke, E.S. Potential shifts in dominant forest cover in interior Alaska driven by variations in fire severity. Ecol. App. 2011, 21, 2380-2396. [CrossRef]

(C) 2020 by the authors. Licensee MDPI, Basel, Switzerland. This article is an open access article distributed under the terms and conditions of the Creative Commons Attribution (CC BY) license (http://creativecommons.org/licenses/by/4.0/). 